\section{Genetic engineering}

\section{USDA goes too public too quickly}

Washington

THE US Department of Agriculture (USDA) appeared to have shot itself in the foot last week when it disclosed that its licensing division approved for sale on 16 January the world's first genetically engineered live virus vaccine without informing its own Agricultural Recombinant DNA Research Committee (ARRC). Senior researchers at the department who sit on ARRC were fuming that they found out only at second hand.

The vaccine, developed and sold by Biologics Corporation of Omaha, Nebraska, prevents pseudorabies, which is caused by a herpes virus that primarily affects pigs, killing young animals. Antibody-positive animals have to be slaughtered, and an infected herd can transmit the virus to cows and sheep, in which it is fatal.

USDA is trying to eradicate the disease in the United States by a vaccination programme. One was vaccine, sold as "Omnivac", employs an engineered Bucharest strain of pseudorabies virus, patented by Dr Saul Kit and Dr Malon Kit of Novagene Inc. The engineered virus lacks the thymidine kinase gene apparently responsible for the pathogenic effect of the wildtype virus and which allows the virus to "hide" in latent form in the central nervous system.

Dr George Shibley, of USDA's biologics licensing division, says that the product had been approved after extensive field tests last year had established the safety and efficacy of the vaccine to the division's satisfaction. Division head David Espereth said proper procedures had been followed and that formal review by ARRC "would not have added anything" because the genetic engineering had involved only a deletion, not the introduction of a foreign gene. The division had established that host range and virulence were unchanged, but did not consider use of a vaccine to constitute an environmental release and so believed that no formal assessment of environmental consequences was necessary. Shibley pointed out that other artificially selected pseudorabies live vaccines are already on the market, and that the division has previously approved inactivated genetically engineered viral vaccines.

Shibley says the application was mentioned informally "two or three times" at ARRC meetings. But others on the committee deny hearing anything about it and consider that a formal notification should have been made. Another proposal to re-

SDI lease genetically engineered organisms (tobacco plants) made by Calgene has been under review by ARRC for a year John Fulkerson of USDA's research division believes that, whether or not formal procedures were violated, the Biologics Corporation proposal should have been fully discussed in the department and by others if necessary. Shibley concedes that, with hindsight, he would have raised it formally in ARRC.

The controversy has been music to the ears of opponents of genetic engineering and will do little to reassure an apprehensive public that biotechnology is under adequate control; Jeremy Rifkin of the
Foundation on Economic Trends claimed on the front page of the New York Times that USDA violated federal guidelines. And less than three weeks ago a California biotechnology company, Advanced Genetic Sciences, was fined $\$ 20,000$ and had its permit to conduct field tests of a genetically engineered microorganism suspended for falsifying test data.

Independently of the Omnivac rumpus. the General Accounting Office (GAO) last week released a report critical of USDA's biotechnology regulatory activities. In particular, it found that ARRC had neither the authority nor the direction to act effectively now that the Recombinant DNA Advisory Committee of the National Institutes of Health has agreed to assume a lesser role in regulation of nonbiomedical biotechnology. USDA, with other government agencies, will shortly be publishing revised policy guidelines for regulating recombinant DNA products and research.

\title{
Senators' scepticism fortified
}

Washington

OF the controversy still raging around the Strategic Defense Initiative (SDI) programme of research into ballistic missile defences, the most recent and scathing is a study of SDI carried out for three US senators and made public last week. It concludes that there have been "no major breakthroughs" to make deployment of a ballistic missile defence more feasible since President Reagan announced SDI three years ago.

The study warns that the current SDI research programme, which requires a decision on development of a missile defence system to be made in the early 1990s, could compromise promising long-term research by imposing an arbitrary schedule. And, in its effort to maintain public support, the study says, SDI may degenerate into what one senior scientist calls "a series of sleazy stunts".

The claim that there have been no major breakthroughs contradicts public statements by several administration officials. Former White House science adviser George Keyworth, for example, has said that the United States will be able to demonstrate technical feasibility of a laser-based defence in the early 1990s. Secretary of Defense Caspar Weinberger has spoken of barriers to progress "crumbling".

The Senate study, based on interviews with SDI researchers, was conducted by staff of Senators Proxmire, Johnstone and Chiles, Democrats on the Senate defence subcommittee who have been critical of what they see as excessive spending on SDI. Although not a comprehensive technical assessment, the study (which is seen by the Pentagon as unduly pessimistic) will do nothing to change the senators' views.

The study acknowledges that several SDI projects have yielded results. But it says there are still "myriad uncertainties" about the programme as a whole. and that, on key points, the difficulties have become more serious than previously recognized. The study reports that SDI researchers at Sandia National Laboratory have concluded that space-based boost phase defences - which many consider an essential component of a credible anti-ballistic system -- can never be made survivable, unless by treaty.

The study warns Congress to be critical about priority shifts made in SDI in an effort to keep on schedule, and points to contract overruns that have already obliged the Pentagon`s SDI organization to settle for second-best components. The study urges Congress to delay a decision on whether to proceed with development beyond the early $1990 \mathrm{~s}$

Whatever the technical problems, SDI's political battles are far from over. Although there is a strong consensus in Congress in favour of research into missile defences, how a candidate system would be tested without violating the 1972 antiballistic missile treaty remains unclear. The Pentagon has re-evaluated the treaty and concluded that it does not after all forbid testing in space - contrary to previous interpretations and the views of some other government agencies. Pressure to abandon the restrictive interpretation can be expected to increase as possible SDI weapons demonstrations approach the testing stage.

Tim Beardsley 